\title{
A MAGYARORSZÁGI LAKÓTELEPEK KISKERESKEDELMI PROFILJA ${ }^{1}$
}

\author{
(Forms of Retailing in Housing Estates of Hungary)
}

\section{MICHALKÓ GÁBOR ${ }^{2}-$ HEGEDÜS SÁRA ${ }^{3}$}

Kulcsszavak:

kiskereskedelem lakótelep üzlet

A szocialista lakásépitési program termékeként számon tartott lakótelepek kereskedelmi egységeinek elsö számú küldetése az ellátásban testet öltõ funkcionalitás volt. A tervezök minimális energiát fordítottak az üzletek formavilágára. Tanulmányunkban 16 évvel a rendszerváltozás után azt vizsgáljuk, hogy mennyiben tér el ma a lakótelepek üzleteinek arculata a hagyományos beépitésũ városrészekben található társaikétól. Egy 2045 üzletre kiterjedõ országos felmérés eredményeként értékeljuik a kirakatban található arucikkek összetételében, az árak kiírásában, az üzletek fekvésében, a cégtáblák és a kirakatok jellegében észlelhetô differenciákat.

\section{Bevezetés}

A társadalom életterének igen fontos szegmensét képezi, a kiskereskedelmi szféra egységeinek minőségi és mennyiségi mutatóiban megtestesülö ellátás színvonala (Berényi 2003; Sikos 2000). Ez a tényezö a lakókörnyezet komplex értékelésében is közrejátszik, többek között befolyásolja az ingatlanárakat, ezzel összefüggésben a kereslet területi preferenciáit (Kovács-Wiessner 1996). Természetesen a változó fogyasztási szokások, a hipermarketek iránti fokozott érdeklödés hatással vannak az ellátás szerepének megítélésére, azonban elvitathatatlan, hogy a kiskereskedelem állapota a belvárosi, a zöldövezeti vagy a lakótelepi zónákban egyaránt kulcsfontosságú az életminőség tekintetében (Nagy 1998). Magyarország lakótelepeinek társadalmi megítélése kedvezötlen, a „lakótelepi szindróma" fogalomkörébe az uniformizált épületek, az ingerszegény környezet, az ingatlanok magas rezsi költségei csakúgy beletartoznak, mint a kiskereskedelmi ellátás egysíkúsága (Egedy 2000, 2001). A lakótelepek társadalmának életérzését, illetve a külsỏ szemlélő ottani viszonyokról alkotott képét az üzletek kínálata és a külsó megjelenése, vagyis a profilja egyaránt befolyásolja. A szocializmus korának tervezői nem álmodhattak elegáns üzletsorokat, árutól roskadozó kirakatokat a panelek utcafrontjára, mivel a fölszinti épületrészeket az ún. szociális helységek (kerékpár- és babakocsi-tároló, szárító) foglalták el, amelyek kihasználatlanságuk miatt szélesebb körben csak a rendszerváltozás környékén kaphattak új funkciókat (Csizmady 2003). Az ellátást hosszú ideig a házsorok között megbúvó lakótelepi közértek és a szolgáltatóházak biztosították. Mára a helyzet az építészeti és a szociális lehetőségek keretein belül átalakulófélben van, a panelrengetegben élök kiskereskedelmi kereslete indukálja a 
belvárosi egységek profiljához való közeledést. Az üzletek modernizációja a lakótelepekre kiterjedő városrehabilitációs programok megkerülhetetlen elemét képezi (Csizmady 2005).

Tekintettel arra, hogy a kiskereskedelmi szféra átalakulásának sajátos szociálgeográfiai szegmensét képező lakótelepi folyamatokról időbeli összehasonlításra alkalmas információk nem állnak rendelkezésre, ezért ebben a tanulmányban 2004 vonatkozásában mutatjuk be a lakótelepek és a hagyományos belvárosi területek üzleteinek profilját jellemző legfontosabb mutatókat. A munka szerves elözményének tekinthetö annak az országos felmérésnek az eredménye (Michalkó-Hegedüs 2005), amely a lakótelepeken túlmenően a hagyományos beépítésủ városrészek, a city-k egyes kiskereskedelmi jellemzőire is kiterjedően ad komplex áttekintést Budapest és a vidéki városok helyzetéröl. E helyen elsősorban arra a kérdésre keressük a választ, hogy milyen összefüggés mutatható ki az eltérő jellegủ városrészekben elhelyezkedő kiskereskedelmi egységek müszaki, információs és kínálati struktúrája között. Miután áttekintést adunk a lakótelepi üzletek általános profiljáról (bemutatjuk az elhelyezkedésüket, az árucikkek körét, a nyitva tartás jellegzetességeit), kereszttáblák segítségével megpróbálunk kapcsolatokat keresni a paneltérbeli pozíciójuk egyes elemei között.

\section{Módszertan}

Tekintettel arra, hogy a kutatás pontos módszertana a Földrajzi Értesítöben megjelent tanulmányban (Michalkó-Hegedüs 2005) ismertetésre került, ezért itt csak a legfontosabb paramétereket adjuk közre. A 2004-ben lezajlott kutatásban közremüködö kérdezöbiztosok 28 magyarországi városban és Budapest 13 kerületében, településenként (Budapesten városrészenként) 50 üzlet profiljára vonatkozóan végeztek megfigyeléseket. A számítógépes adatbázisban összesen 2045 kiértékelésre alkalmas kérdöív információit rögzítettük.

A Központi régióból Budapest 13 kerületében, Érden és Szentendrén, a KözépDunántúli régióból Székesfehérváron, Dunaújvárosban, a Nyugat-dunántúli régióból Győrött, Csornán, Mosonmagyaróváron, Sopronban, Zalaegerszegen, Zalaszentgróton és Nagykanizsán, a Dél-dunántúli régióból Pécsett, Kaposváron és Marcaliban, a Délalföldi régióból Szegeden, Kisteleken, Kecskeméten, Hódmezővásárhelyen és Szentesen, az Észak-alföldi régióból Debrecenben, Szolnokon, Karcagon, Kisújszálláson, Püspökladányban és Hajdúdorogon, az Észak-magyarországi régióból Ózdon, Miskolcon és Sárospatakon végeztünk megfigyeléseket.

A felmérés során 19 vidéki városban belvárosi (hagyományos beépítésü) és lakótelepi városrészben is, 9 településen pedig csak belvárosi területen végeztünk megfigyeléseket. Budapesten a hagyományos városi beépítésủ területek közé soroltuk a II., az V., a VI., a VII., a VIII., a IX. és a XI. keruilet megfigyelt helyszíneit. A lakótelepi üzletek megfigyelését a III., a X., a XIII., a XV., a XVII. és a XVIII. kerületben végeztük el. A megfigyelt üzletek 31,6\%-a a fövárosban, 68,4\%-a vidéki városokban található. A kérdezőbiztosok minden megfigyelt kiskereskedelmi egység vonatkozá- 
sában egy, a kutatás elözményét képező, 1995-ös felmérés adatlapjával kompatíbilis, úgynevezett üzlet-adatlapot töltöttek ki, a szükséges információkat egyszerü szemrevételezéssel gyüjtötték be.

Figyelembe véve, hogy a területi különbségek értékelésére korábban már sor került, ebben a tanulmányban a bevezetőben ismertetett célkitüzésnek megfelelően kizárólag a lakótelepek vonatkozásában végzünk elemzéseket. A kereszttáblák összeállitásánál a táblában szereplő megoszlások az adott változókra adott válaszok százalékos arányát tükrözik, de mivel az átláthatóság kedvéért csak a legjellemzőbb válaszokat emeltük ki, így a cellák összesítése - értelemszerüen - nem adja ki a 100 százalékot.

\section{Eredmények}

\section{Általános profil}

A magyarországi lakótelepeken müködő kiskereskedelmi egységek döntő többsége - a hagyományos beépítésủ városrészek üzleteihez hasonlóan - közvetlenül az utcáról nyílik. A vidéki városok lakótelepein az üzletek bejáratainak 89,9\%-a, Budapesten 82,8\%-a utcafronti. Vidéken 7,6\%, Budapesten 7,8\% a lakótelepeken található kiskereskedelmi egységek udvari bejáratainak az aránya. A megközelítésükkel szoros összefüggésben áll, hogy a lakótelepi üzletek szinte teljes körủen a földszinten helyezkednek el. Vidéken (96,7\%) és Budapesten (96\%) is valamivel magasabb a földszinten található lakótelepi üzletek aránya, mint a hagyományos beépítésủ városrészekben található társaiké.

A lakótelepi üzletek alapvetően kereskedelmi tevékenységet folytatnak, de előfordul, hogy ezt bizonyos szolgáltatásokkal is bỏvítik. Vidéken $(78,8 \%)$ valamivel alacsonyabb a tisztán kereskedelmi tevékenységet folytató üzletek aránya, mint Budapesten $(82,3 \%)$, ugyanakkor Budapesthez képest $(13,3 \%)$ vidéken magasabb (16,3\%) a kereskedelmi és szolgáltató tevékenységet egyaránt megjelenítő egységek aránya.

A lakótelepi üzletek árukinálatának főcsoportjait tekintve érdemi különbség mutatható ki a hagyományos beépítésü városrészben található üzletekkel történő öszszehasonlítás során. A lakótelepeket vidéken és Budapesten is az élelmiszerüzletek markánsabb kínálata jellemzi. Amíg a vidéki városokban a hagyományos beépítésü városrészekben az élelmiszerüzletek aránya 17\%, addig a lakótelepeken $31,2 \%$, ugyanebben a területi relációban Budapesten 15,3\% és 23,6\% a megfigyelt élelmiszerüzletek aránya. Ezzel összefüggésben a tartós fogyasztási cikkeket, ruházatot és lábbelit kínáló boltok részesedése alacsonyabb a lakótelepeken.

A lakótelepek nemcsak az áruföcsoportokban, hanem az egyes konkrét termékek kínálatában is jellegzetes eltérést mutatnak a hagyományos beépítésủ városrészekhez képest. Amennyiben a vizsgálat során megfigyelt összes kiskereskedelmi egység kínálati megoszlásában vezető helyen szereplő árucikkeket vesszük alapul, akkor megállapíthatjuk, hogy a magyarországi lakótelepeken az általános élelmiszerek, az édességek, a cigaretta, az alkohol, a kávé, a kozmetikumok és a zöldséggyümölcs félék nagyobb arányban fordulnak elö, mint a hagyományos beépítésü 
városrészek üzleteiben. Ezzel szemben a ruházatban, a cipőben, az öltözködéskiegészítökben, a játék és ajándékokban, az óra-ékszer-szemüveg területén a lakótelepi boltok kínálata a hagyományos beépítésü városrészekkel összehasonlítva alacsonyabb arányt képvisel. Az egyes termékek részarányában jelentkező differenciát figyelembe véve a hagyományos beépítésü városrészek üzleteihez képest a legnagyobb elmaradás a ruházat $(-16,7 \%)$ és az öltözködés-kiegészítők területén érhetö tetten $(-11,1 \%)$, míg a legeröteljesebb kínálati többlet a cigaretta $(+10,7 \%)$ és az általános élelmiszerek területén $(+9,1 \%)$ mutatható ki, elóbbit Budapesten, utóbbit a vidéki városok lakótelepein észlelték (1. ábra).

\section{1. ÁBRA}

Az egyes árucikkek megoszlásában jelentkezö differencia a lakótelepek és a hagyományos beépitésü városrészek vonatkozásában(\%)

(Differences in the Distribution of the Commodities Merchandised in the Stores of Housing Estates and in those of Traditional Urban Quarters)

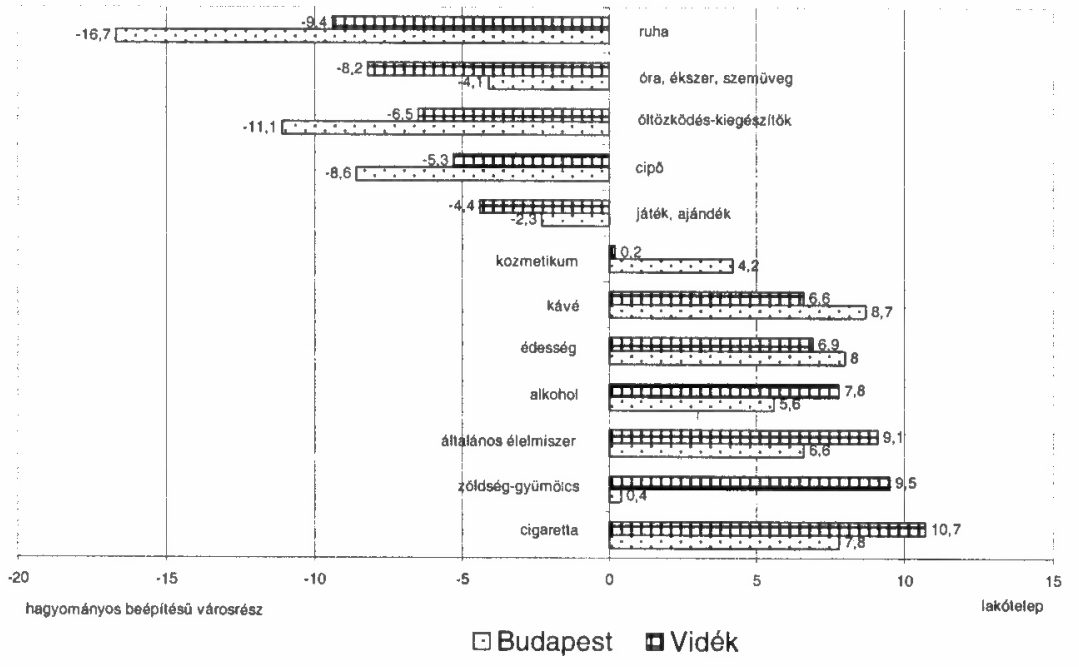

Forrás: Saját szerkesztés.

Ami az üzletek nyitva tartását illeti, megállapítható, hogy a lakótelepek üzletei hétköznap és hétvégén egyaránt hosszabb ideig állnak a vásárlók rendelkezésére, mint a hagyományos beépítésú városrészek egységei. A vidéki lakótelepeken hétfötöl péntekig 46,18 óra a nyitvatartási idő, míg a szombatot és a vasárnapot együttvéve 7,95 óra, ugyanebben a relációban Budapesten 46,29, illetve 8,28 óra áll a vásárlók rendelkezésére. Az igazán jelentős differencia a hétvégi nyitvatartásban érhető tetten, mivel vidéken 2,59 órával, Budapesten pedig 2,89 órával hosszabb a vásárlók számára biztosított idő. Ha figyelembe vesszük a nyitvatartási napok számát, akkor az egy napra esỏ nyitvatartási időben a budapesti lakótelepek vezetnek ( 9,00 óra), ezt a vidéki lakótelepek ( 8,96 óra) és a budapesti hagyományos beépítésủ városrészek ( 8,60 óra) követik, míg a legrövidebb egy napra eső nyitva tartási időt a vidéki hagyományos beépítésủ városrészek ( 8,17 óra) üzletei mutatják. 


\section{Külsö profil}

Akár a vidéki, akár a budapesti hagyományos beépítésü városrészeket hasonlítjuk össze a lakótelepekkel, megállapíthatjuk, hogy a hagyományos beépítés esetében az üzletsor tagjaként (vidéken $34,6 \%$, Budapesten $25,8 \%$ ) vagy önálló üzlethelységként (vidéken 34,3\%, Budapesten 47,3\%) megjelenő kiskereskedelmi egységek aránya a lakótelepinél magasabb, míg vidéken mindkét típusban $10 \%$ körüli, addig Budapesten 5, illetve 7\% különbséget lehet kimutatni az elöbbi javára. Miközben a lakótelepeken az összes megfigyelt kiskereskedelmi egységből az üzletsor tagjaként vagy önálló üzlethelységként számba vett boltok aránya a hagyományos beépítésü városrészekhez hasonlóan magas, esetükben sokkal markánsabban jelennek meg az önálló épületben (vidéken 16,4\%, Budapesten 20,9\%) vagy a más célra épült helységből kialakított terekben (vidéken 25,7\%, Budapesten 3,6\%) megtalálható üzletek. Figyelemre méltó, hogy a más célra épült helységböl kialakított üzletek sokkal inkább a vidéki városok lakótelepein jelennek meg szemben a budapestiekkel, ahol az önálló épületben lévő ủzletek aránya a magasabb.

Ami a lakótelepeken található kiskereskedelmi egységeknek teret adó épületek állagát illeti, elmondható, hogy a vidéki és a fóvárosi lakótelepek is az „elég jó állapotú" minősítéssel illethetők, a vidéki lakótelepi üzletek 47,3\%-a, míg a fővárosi társaik 41,2\%-a esett ebbe a kategóriába. A lerobbant lakótelepi üzletek aránya vidéken valamivel magasabb $(15,2 \%)$, míg a fövárosban a hagyományos beépítésü területeken el helyezkedỏ rossz állapotú üzletek arányával egyezik meg (10\%).

\section{TÁBLÁZAT}

Az üzletek jellege és épületük állaga közötti összefüggések Magyarországon, 2004 (\%)

(Character of the Retail Units and Physical State of the Buildings, 2004, \%)

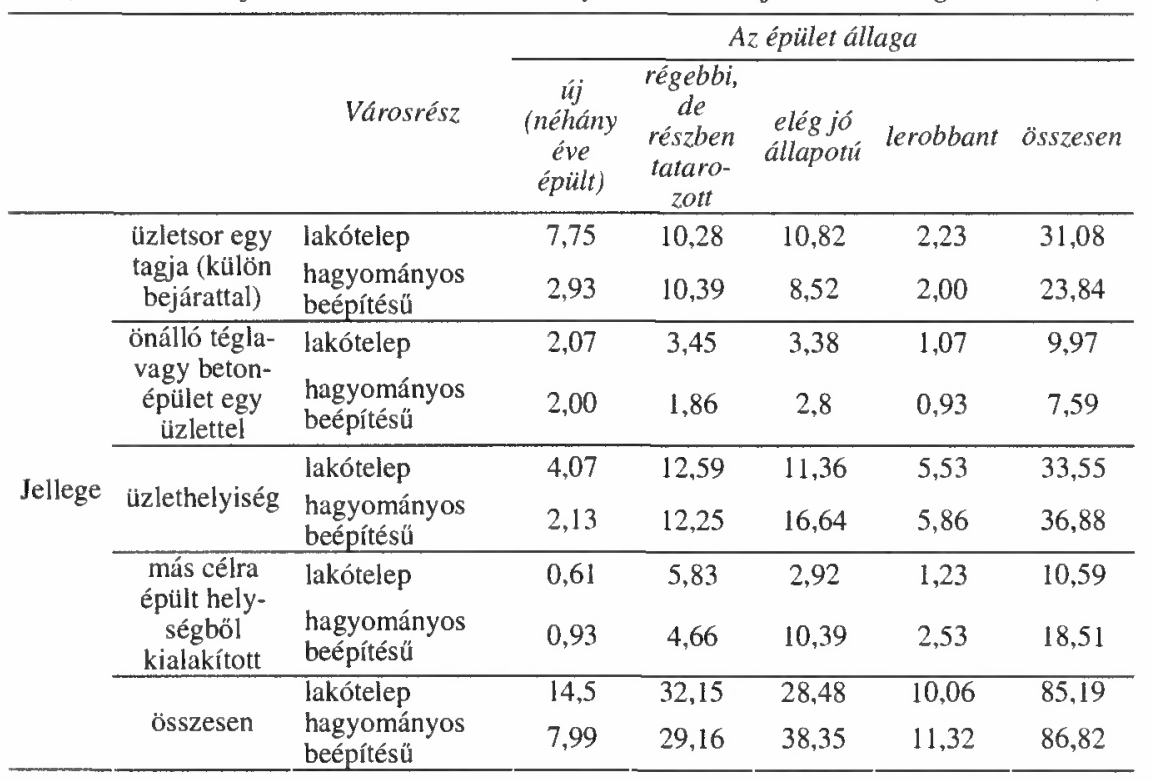

Forrás: Saját adatgyüjtés. 
Amennyiben összefüggést keresünk az épületek jellege és állaga között, láthatjuk, hogy jelentősebb aránybeli különbségeket mindössze egy-két esetben tudunk kimutatni (1. táblázat). Ưj építésü, üzletsor egy tagjaként, külön bejárattal ellátott egységekkel inkább a lakótelepeken találkozhatunk, elég jó állapotú üzlethelység azonban a hagyományos beépítésủ városrészekben fordul elő számottevően magasabb arányban. A legnagyobb, mintegy háromszoros differencia a más célra épült helységböl kialakított üzletek esetében fordult elö, elég jó állapotban leginkább a hagyományos városrészekben találkozhatunk velük. Az észleltek magyarázatául szolgálhat, hogy a hagyományos beépítésủ városrészekben a lakó és az ellátási funkció eröteljesebb eltolódásáról kell beszélnünk, mivel a lakások utólagos üzletekké való átalakítása inkább itt következett be. Annak ellenére, hogy az ellátást a lakótelepek kialakításakor már sokkal tudatosabban tervezték meg, mára ezekben a városrészekben is tetten érhetö az észlelt jelenség.

\section{Információs profil}

A kirakatok típusait vizsgálva megállapítható, hogy a vidéki és a fövárosi lakótelepek esetében is a bolt felé nyitott, az üzletbe való belátást biztosító, áruval ellátott kirakatok a dominánsak. Ez vidéken a megfigyelt lakótelepi üzletek harmadát $(31,4 \%)$, Budapesten a felét $(52,8 \%)$ jellemzi. A megoszlásuk megegyezik a hagyományos beépítésủ városrészben elhelyezkedő üzletek kirakatainak típusaival. Valódi különbség a bolt felé nyitott, az üzletbe való belátást biztosító, azonban üres kirakatok esetében mutatható ki. Ebben a típusban vidéken a lakótelepek részesedése duplája $(28,7 \%)$ a hagyományos beépítésü városrészekének, de a budapesti lakótelepeken is jóval magasabb arányt $(23,2 \%)$ képviselnek. A klasszikusnak mondható kirakattípusban a vidéki lakótelepek $(20,4 \%)$ ugyan erősebbek, mint a fővárosiak $(5,6 \%)$, azonban a hagyományos beépítésủ városrészekkel való összehasonlításban mindkét településen alacsonyabb részesedést mutatnak. Az utcára a bolt elé kirakott, kiakasztott árukat vizsgálva vidéken nem mutatható ki különbség a lakótelepek $(7,5 \%)$ és a hagyományos beépítésủ városrészek $(7,4 \%)$ viszonylatában, Budapesten azonban az áruk ilyetén kínálása a lakótelepeket $(5,6 \%)$ kevésbé jellemzi.

A kiskereskedelmi egységek által kínált termékek fogyasztói árának megjelenítésében igen jelentős különbségek mutathatók ki a lakótelepi és a hagyományos beépítésü városrészek között. A lakótelepi üzletek jóval magasabb arányban nem jelenítik meg a kínált termékek fogyasztói árát, mint a hagyományos beépítésü városrészek. Ez a jelenség vidéken a lakótelepi üzletek $68 \%$-át, Budapesten pedig $76 \%$-át jellemzi, míg a hagyományos beépítésủ városrészekben $50 \%$ körül marad. 
Michalkó Gábor - Hegedüs Sára : A magyarországi lakótelepek kiskereskedelmi profilja Tér és Társadalom 20. évf. 2006/1. 125-135. p.

TÉT XX. évf. 2006 - 1

Gyors ténykép

131

\section{TÁBLÁZAT}

Az üzletek kirakata és az árak kiúrása közötti összefüggések Magyarországon, 2004 (\%) (Portals of the Shops and Display of Prices, 2004, \%)

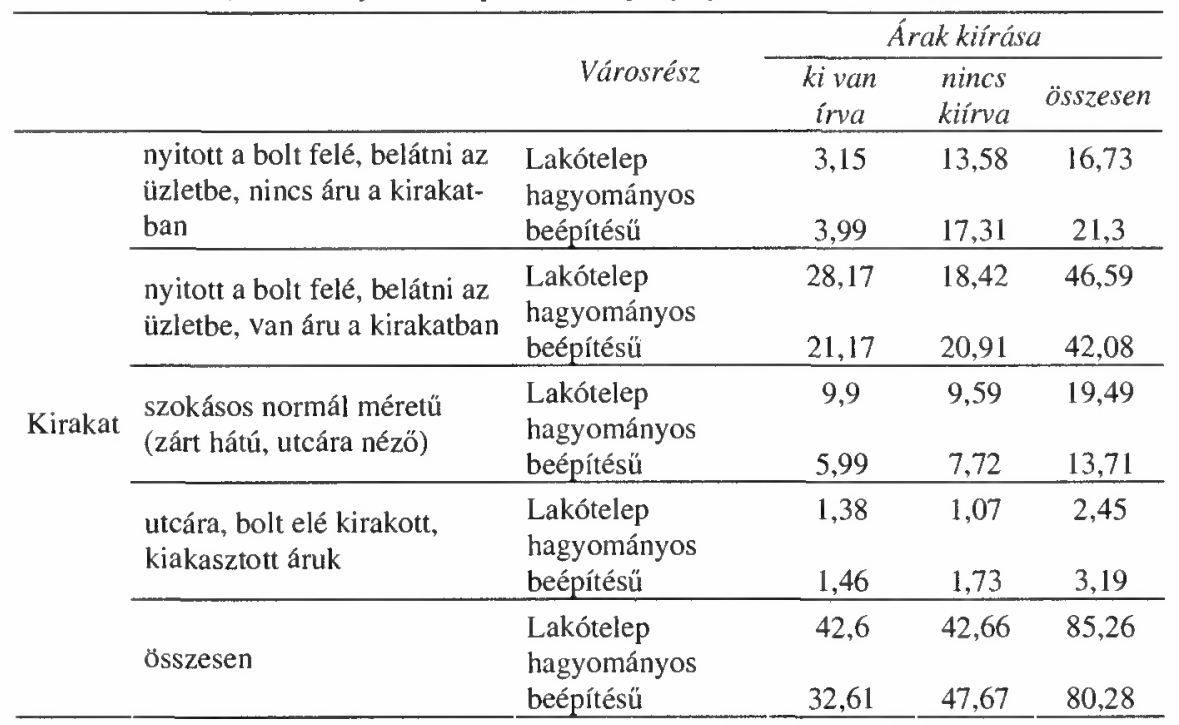

Forrás: Saját adatgyüjtés.

Amennyiben összefüggést keresünk a kirakatok típusa és az árak külső megjelenítése között, megállapíthatjuk, hogy bizonyos befolyásoló hatás mutatható ki a lakótelepen és a hagyományos beépítésủ városrészben müködő üzletek relációjában (2. táblázat). Ahol nincs áru a bolt felé nyitott, az üzletbe való beláthatóságot biztosító kirakatokban, ott a fogyasztói árak kírása is alacsonyabb valószínúségủ lesz, ugyanakkor elmondható, hogy a hagyományos beépítésü városrészekben magasabb azon üzletek aránya, ahol a kérdezőbiztosok nem észlelték az árak megjelenítését. A kirakatokban elhelyezett termékek maguk után vonzzák fogyasztói áraik kiírását, az ilyen típusú kirakatokban a lakótelepeken magasabb arányban észleltük az árfeltüntetést. Sem a klasszikus kirakatoknál, sem az utcára vagy a bolt elé kirakott, kiakasztott áruk kapcsán nem tapasztaltunk érdemleges különbséget az árak kiírása és az üzlet területi elhelyezkedése között.

Az árak kiírása kapcsán az üzlet közvetlen környezetében megjelenő reklámokat is vizsgáltuk (3. táblázat). Általánosságban megállapítható, hogy a nem nyomtatott, hanem az üzlet környékén elhelyezett klasszikus, „címfestett” reklámlehetőségekkel nem élnek a boltosok. Ebben a tekintetben jelentős különbség nem mutatható ki a lakótelepi és a hagyományos beépítésủ városrészek üzletei között. A vidéki lakótelepeken inkább a járdán elhelyezett figyelemfelkeltő tábla, míg Budapesten a bolttól távolabb levő „terelő” tábla a jellemző. A járdán elhelyezett figyelemfelkeltő tábla esetén nagyobb valószínüséggel vannak kiírva az árak, mint a bolttól távolabbi terelỏ táblák kapcsán, ebben a tekintetben a lakótelepi és a hagyományos beépítésü városrészek között nincs érdemi differencia. Ahol nincs semmilyen reklámtábla, ott 
az árak megjelenítése is gyakrabban marad el, a lakótelepek mintegy $40 \%$-ában, a hagyományos beépítésú városrészek felében nincsenek feltüntetve az árak akkor, ha reklámtábla sincs.

\section{TÁBLÁZAT}

Az üzletek reklámja és az árak kiírása közötti összefüggések Magyarországon, 2004 (\%) (Advertising of the Shops and Display of Prices, 2004, \%)

\begin{tabular}{|c|c|c|c|c|c|}
\hline & & \multirow{2}{*}{ Városrész } & \multicolumn{3}{|c|}{ Árak kiírása } \\
\hline & & & ki van írva & nincs kirrva & összesen \\
\hline \multirow{8}{*}{ Reklám } & $\begin{array}{l}\text { járdán elhelye- } \\
\text { zett figyelem- }\end{array}$ & $\begin{array}{l}\text { lakótelep } \\
\text { hagyományos }\end{array}$ & 6,6 & 6,22 & 12,82 \\
\hline & felkeltő & beépítésü & 4,66 & 5,73 & 10,39 \\
\hline & $\begin{array}{l}\text { a bolttól távo- } \\
\text { labb elhelyezett }\end{array}$ & $\begin{array}{l}\text { lakótelep } \\
\text { hagyományos }\end{array}$ & 1,84 & 4,14 & 5,98 \\
\hline & „terelő” & beépitésü & 1,2 & 5,59 & 6,79 \\
\hline & \multirow[t]{2}{*}{ nincs } & $\begin{array}{l}\text { lakótelep } \\
\text { hagyományos }\end{array}$ & 34,84 & 39,37 & 74,21 \\
\hline & & beépítésü & 28,89 & 48,2 & 77,09 \\
\hline & \multirow[t]{2}{*}{ összesen } & $\begin{array}{l}\text { lakótelep } \\
\text { hagyományos }\end{array}$ & 43,28 & 49,73 & 93,01 \\
\hline & & beépítésü & 34,75 & 59,52 & 94,27 \\
\hline
\end{tabular}

Forrás: Saját adatgyüjtés.

A cégér megjelenítése, vagyis a kiskereskedelmi üzletek nevének, az általuk kínált árucsoportnak, egyes kiemelt termékeiknek, akcióiknak a feltüntetése megkerülhetetlen elemét képezi a sikeres kínálat kialakításának. A lakótelepi üzletek a hagyományos beépítésủ területekhez hasonlóan kiemelt figyelmet szentelnek a cégtábla kialakítására. A különbségek elsősorban a cégér minőségi jegyei és a vidé$\mathrm{ki}$, budapesti területek között mutathatók ki. Amíg vidéken a lakótelepi üzleteket a szolid kiírás (48,8\%), addig Budapesten a nagyméretü cégtábla (72,3\%) jellemzi. A hagyományos beépítésú területekkel szemben designes portál kialakítása a lakótelepeken kevésbé fordul elö.

A boltokat üzemeltető vállalkozások cégformájának feltüntetése nem tartozik a cégtáblák preferált elemei közé. Sem vidéken, sem Budapesten nem észlelhetö érdemi különbség abban a tekintetben, hogy lakótelepen vagy hagyományos beépítésủ városrészben vizsgáljuk a vállalkozás formájának megjelenítését. Vidéken megközelítőleg a lakótelepi üzletek fele, Budapesten $80 \%$-a nem írja ki, hogy a tulajdonos milyen cégformában üzemelteti az egységet.

A mennyiben összefüggést keresünk az üzletek által kihelyezett cégtábla típusa és az üzemeltetỏ vállalkozás cégformája kỏzött, akkor elsősorban a kiírás hiánya kapcsán érhetünk tetten bizonyos kapcsolatokat (4. táblázat). Legkisebb arányban a designes portált alkalmazó boltok esetében kerülik el a vállalkozás formájának feltüntetését. A designes portállal rendelkezỏ lakótelepi üzletek esetében kisebb a valószínúsége a vállalkozási forma feltüntetésének, mint a hagyományos beépítésü városrészekben. Az országos hálózattal rendelkezö boltok mind a designes portál, 
Michalkó Gábor - Hegedüs Sára : A magyarországi lakótelepek kiskereskedelmi profilja Tér és Társadalom 20. évf. 2006/1. 125-135. p.

TÉT XX. évf. 2006 - 1

Gyors ténykép

133

mind pedig a szolid cégtábla esetében nagyobb hangsúllyal a lakótelepeken, míg a nagyméretü cégtábla alkalmazásakor inkább a hagyományos beépítésủ városrészekben szerepeltetik a cégformát. Az egyéni vállalkozók minden cégtábla típus esetében a lakótelepeken tüntetik fel nagyobb arányban cégformájukat.

\section{TÁBLÁZAT}

Az üzletek cégtáblája és a vállalkozási forma közötti összefiuggések Magyarországon, $2004(\%)$

(Labels of the Shops and Form of Entrepreneurship, 2004, \%)

\begin{tabular}{|c|c|c|c|c|c|c|c|c|c|}
\hline & & \multirow[b]{2}{*}{ Városrész } & \multicolumn{7}{|c|}{ Vállalkozás formája } \\
\hline & & & Rt. & $K f t$ & Bt. & $\begin{array}{c}\text { egyéni } \\
\text { vállalkozó }\end{array}$ & $\begin{array}{c}\text { országos } \\
\text { hálózat }\end{array}$ & $\begin{array}{l}\text { nincs } \\
\text { kiírva }\end{array}$ & összesen \\
\hline \multirow{8}{*}{ Cégtábla } & \multirow{2}{*}{$\begin{array}{l}\text { designes } \\
\text { portál }\end{array}$} & \multirow{2}{*}{$\begin{array}{l}\text { lakótelep } \\
\text { hagyományos } \\
\text { beépítésü }\end{array}$} & 0,84 & 2,84 & 1,15 & 1,84 & 2,76 & 6,98 & 16,41 \\
\hline & & & 0,13 & 1,46 & 0,4 & 1,07 & 1,86 & 10,25 & 15,17 \\
\hline & \multirow{2}{*}{$\begin{array}{l}\text { nagyméretủ } \\
\text { cégtábla }\end{array}$} & \multirow{2}{*}{$\begin{array}{l}\text { lakótelep } \\
\text { hagyományos } \\
\text { beépítésủ }\end{array}$} & 1,23 & 3,91 & 1,84 & 4,60 & 3,99 & 26,40 & 41,97 \\
\hline & & & 1,33 & 2,66 & 1,86 & 3,60 & 4,26 & 23,97 & 37,68 \\
\hline & \multirow{2}{*}{$\begin{array}{l}\text { szolid } \\
\text { kiírás }\end{array}$} & \multirow{2}{*}{$\begin{array}{l}\text { lakótelep } \\
\text { hagyományos } \\
\text { beépítésü }\end{array}$} & 0,61 & 3,45 & 1,92 & 6,29 & 1,61 & 19,03 & 32,91 \\
\hline & & & 0,8 & 3,60 & 2,93 & 5,06 & 1,20 & 22,64 & 36,23 \\
\hline & \multirow{2}{*}{ összesen } & \multirow{2}{*}{$\begin{array}{l}\text { lakótelep } \\
\text { hagyományos } \\
\text { beépítésú }\end{array}$} & 2,68 & 10,2 & 4,91 & 12,73 & 8,36 & 52,41 & 91,29 \\
\hline & & & 2,26 & 7,72 & 5,19 & 9,73 & 7,32 & 56,86 & 89,08 \\
\hline
\end{tabular}

Forrás: Saját adatgyüjtés.

\section{TÁBLÁZAT}

Az árak kiírása és az üzletek vállalkozási formája közötti összefïggések Magyarországon, 2004 (\%)

(Display of Prices and Form of Entrepreneurship, 2004, \%)

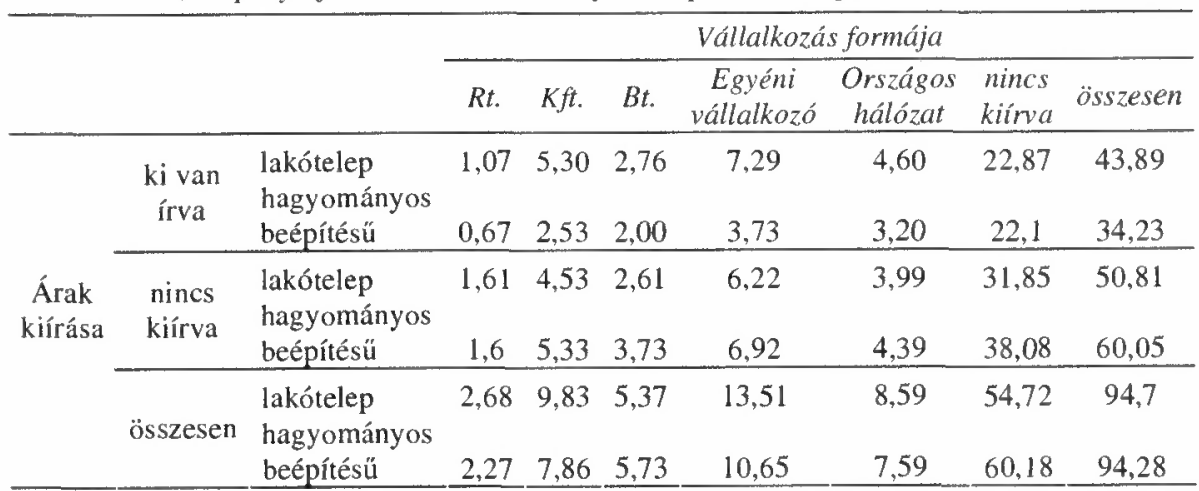

Forrás: Saját adatgyüjtés.

Az árak kiŕrása és a vállalkozás cégformájának megjelenítése közötti kapcsolatok vizsgálata során megállapítható, hogy valamivel nagyobb arányban tüntetik fel azok az áraikat, akik a cégformát is megjelenítik, mint azok, akik ettól eltekintettek (5. táblázat). A lakótelepekkel összehasonlítva a hagyományos városrészekben 
magasabb azon üzletek aránya, amelyekben sem az árakat sem a cégformát nem tüntetik fel. A lakótelepi boltokat üzemeltetỏ egyéni vállalkozók és Kft-k magasabb arányban jelenítik meg az árakat, mint a hagyományos beépítésü városrészben tevékenykedő társaik.

\section{Összegzés}

A lakótelepi üzletek kiskereskedelmi profilja vonatkozásában elvégzett országos elemzés megállapította, hogy az egységek általános jellemzőiben, külső megjelenésében és információközlésében a hagyományos beépítésủ vărosrészekkel összehasonlítva eltérés mutatható ki. Ami a lakótelepi üzletek általános jellemzőit illeti a leginkább szembetünǒ differencia az eladásra kínált termékek összetételében és a nyitvatartási idöben jelentkezik. Az úgynevezett élvezeti cikkekben, mint például az alkohol vagy a cigaretta felülreprezentáltabbak a lakótelepi üzletek, de a nyitva tartási idejük is hosszabb, mint a hagyományos városrészben található társaiké. Ez elsősorban a lakótelepi társadalom sajátos fogyasztási igényével és beszerzési magatartásával hozható összefüggésbe. Az üzletek külső megjelenésében a lakótelepek a más célra épuilt helységböl kialakított boltok vonatkozásában mutatják a legnagyobb arányú különbséget a hagyományos beépítésủ városrészekkel való összehasonlításban, különösen az ilyen típusú, elég jó állapotú egységekben jelentkezik az elmaradás. Ez elsősorban a lakótelepi épületek és terek kötöttségével magyarázható. Az információközlés kapcsán megállapítható, hogy a lakótelepek kirakataiban gyakrabban tüntetỉk fel a termékek árát, mint a hagyományos városrészekben, amit a lakótelepi társadalom szociális helyzetéböl fakadó fokozott árérzékenysége indokol.

$$
\text { Jegyzetek }
$$

' A tanulmányban közölt kutatási eredmények az OTKA T 037247 számú program keretében kerültek feltárásra

${ }^{2}$ Michalkó Gábor geográfus, az MTA Földrajżtudományi Kutatóintézet tudományos fömunkatársa

${ }^{3}$ Hegedús Sára szociológus, a Magyar Turizmus Rt. munkatársa

\section{Irodalom}

Berényi I. (2003) A funkcionális tér szociálgeográfiai elemzése. - Földrajzi Tanulmányok. 23. MTA Földrajztudományi Kutatóintézet, Budapest.

Csizmady A. (2003) A lakótelep. Gondolat. Budapest.

Csizmady A. (2005) A paneles lakótelepek jövője. - Egedy T. (szerk.) Városrehabilitáció és társadalom. MTA Földrajztudományi Kutatóintézet, Budapest. 243-268. o.

Egedy T. (2000) Szegregáció és társadalmi kirekesztés a nagyvárosi lakótelepeken. - Földrajzi Közlemények. 1-4, 93-108. o.

Egedy T. (2001) A lakótelepek társadalmi környezetének átalakulása a rendszerváltozás után. - Földrajzi Értesitô. 1-4, 271-283. o.

Kovács Z.-Wiessner, R. (1996) A lakáspiac átalakulásának föbb jellemzői és városszerkezeti következményei Budapest belsố városrészeiben. - Dövényi Z. (szerk.) Tér-Gazdaság-Társadalom. MTA Földrajtudományi Kutatóintézet, Budapest. 29-48, o. 
Michalkó G.-Hegedús S. (2005) A kiskereskedelmi szféra egyes kínálati elemeinek területi különbségei Magyarországon. - Földrajzi Értesítö. 3-4. 345-364. o.

Nagy E. (1998) Egy hagyományos szerepkör új elemei: a kereskedelem strukturális és térbeli átalakulása Szegeden és Györben. - Mészáros R.-Tóth J. (szerk.) Földrajzi kaleidoszkóp: tanulmányok Krajkó Gyula professzor 70. születésnapjára. JATE TTK Gazdaságföldrajzi Tanszék-JPTE TTK Általános Társadalomföldrajzi és Urbanisztikai Tanszék, Szeged-Pécs. 186-203. o.

Sikos T.T. (2000) Marketingföldrajz. VÁTI. Budapest. 